\title{
Preliminary data on the epigeic beetle fauna (Coleoptera) of the Golczewskie Uroczysko Nature Reserve
}

\author{
BRYGIDA RADAWIEC, ${ }^{1}$ ŁUKASZ BARAN, ${ }^{2}$ PRZEMYSŁAW ŚMIETANA, ${ }^{3}$ \\ EWA SARNACKA, ${ }^{4}$ ANDRZEJ ZAWAL ${ }^{5}$
}

${ }^{1}$ Institute of Biology and Environment protection of Pomeranian University, Arciszewskiego 22b, 76-200 Słupsk, Poland, e-mail: brygida.radawiec@apsl.edu.pl

${ }^{2}$ University of Szczecin, Department of Invertebrate Zoology and Limnology, Institute for Research on Biodiversity, Faculty of Biology, Wąska 13, 71-415 Szczecin, Poland, e-mail: ukaszbaran84@gmail.com

${ }^{3}$ University of Szczecin, Deparment of Ecology \& Environmental Protection, Institute for Research on Biodiversity, Faculty of Biology, 71-415 Szczecin, Wąska 13, Poland, e-mail: przemyslaw.smietana@usz.edu.pl

${ }^{4}$ University of Szczecin, Department of Invertebrate Zoology and Limnology, Institute for Research on Biodiversity, Faculty of Biology, Wąska 13, 71-415 Szczecin, Poland, e-mail: ewa.sarnacka@usz.edu.pl

${ }^{5}$ University of Szczecin, Department of Invertebrate Zoology and Limnology, Institute for Research on Biodiversity, Faculty of Biology, Wąska 13, 71-415 Szczecin, Poland, e-mail: andrzej.zawal@usz.edu.pl, ORCID ID: 0000-0002-5838-6060

Keywords

Abstract epigeic beetles, Coleoptera: Catopidae, Carabidae, Elateridae, Geotrupidae, Silphidae, Staphylinidae, Tenebrionidae, Golczewskie Uroczysko Nature Reserve, West Polish Pomeranian

A study was conducted in May-August 2006 in the Golczewskie Uroczysko Nature Reserve, UTM WV06, using 10 Barber traps containing ethylene glycol. A total of 2,141 beetles were collected, belonging to 58 species from 7 families. The epigeic beetle fauna of the reserve comprised mainly forest, grassland and peatland species. Stable populations of three ground beetle species under partial protection, Carabus convexus, Carabus coriaceus and Carabus glabratus, are present in the forest habitats. The most ecologically valuable species include hygrophilous peatland species: Agonum ericeti (VU), Pterostichus rhaeticus, Agonum hypocrita, Limodromus krynickii, Oodes helopioides (VU), and the rare click beetle Paraphotistus impressus, all of which have poorly known ecological preferences.

\section{Wstępne dane do poznania fauny chrząszczy epigeicznych (Coleoptera) Rezerwatu przyrody "Golczewskie Uroczysko"}

Słowa kluczowe chrząszcze epigeiczne, Coleoptera: Catopidae, Carabidae, Elateridae, Geotrupidae, Silphidae, Staphylinidae, Tenebrionidae, Rezerwat przyrody „Golczewskie Uroczysko”

Streszczenie Badania były prowadzone w maju-sierpniu 2006 roku na terenie Rezerwatu przyrody „Golczewskie Uroczysko”, UTM WV06, za pomocą 10 pułapek ziemnych z glikolem etylenowym. Zebrano 2178 chrząszczy, należących do 71 gatunków z 15 rodzin. Fauna chrząszczy epigeicznych rezerwatu ukształtowana główne przez gatunki leśne, łąkowe i torfowiskowe, W siedliskach leśnych występują stabilne populacje 3 gatunków biegaczy objętych ochroną częściową: Carabus convexus, Carabus coriaceus oraz Carabus glabratus. Do najcenniejszych 
przyrodniczo można zaliczyć hygrofilne gatunki torfowiskowe: Agonum ericeti (VU), Pterostichus rhaeticus, Agonum hypocrita, Limodromus krynickii, Oodes helopioides (VU), oraz rzadki sprężyk Paraphotistus impressus ze słabo poznanymi preferencjami ekologicznymi.

\section{Introduction}

Raised peat bogs in their natural state are currently still found in Ireland, Great Britain, Scandinavia, countries of the former Soviet Union, and Poland (Sjörs, 1983). Marshland and swamps are characteristic of northern and north-eastern Poland. They occupy about $4 \%$ of the area of the country, and raised peat bogs make up $0.2 \%$ (Ilnicki, 2002). According the European Union Natura 2000 directive, raised bogs and marshland are especially valuable habitats (Council Directive 92/43/EEC).

Marshes are destroyed during agricultural practices, drainage and peat extraction. Particularly dangerous for peatlands is the decline in the groundwater level, this is a consequence of dehydration. In Poland it is the main cause of the disappearance of peatlands (Żurek, 1987). For this reason there is a need for intensive research on the fauna of these rare and threatened habitats.

Uroczysko Golczewskie is an ecologically valuable peatland complex containing forest habitats, lakes, raised bogs and transitional bogs (Figure 1).

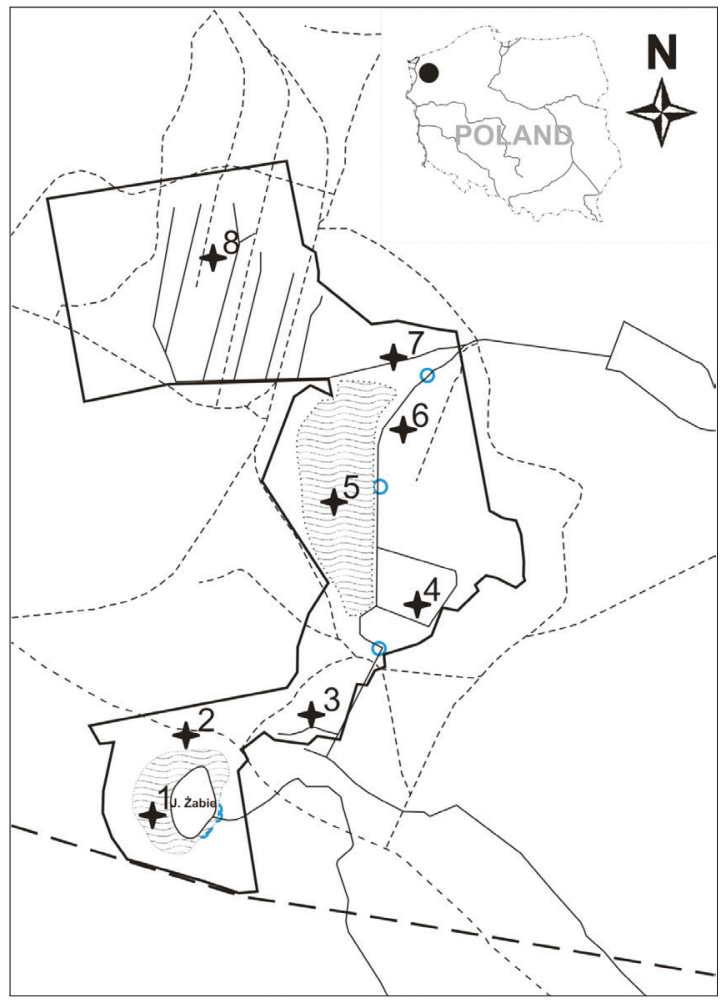

Figure 1. Map of the area with sites where insects were obtained 
In northern and central Europe, research on the ground beetles of raised bogs has a fairly long tradition. It is worth recalling some of the work on this subject: Peus (1928-1932) in northwestern Germany (Mossakowski, 1970), in eastern Prussia (Skwarra, 1929; Främbs et al., 2002; Mossakowski et al., 2003), in the Czech Republic (Roubal, 1934), in Finland (Renkonen, 1938; Krogerus, 1960), and in Belarus (Sushko, 2006; Aleksandrowicz, 2014).

In Poland, the epigeic beetles of raised peat bogs are little known; only the ground beetles (Carabidae) of the "Torfiaki" peatland complex in the vicinity of Olsztyn have been studied (Aleksandrowicz et al., 2017).

\section{Study area}

The Golczewskie Uroczysko nature reserve was established on 5 May 2004 to protect the raised peat bog and the dystrophic Lake Żabie with its surrounding transitional bog and adjacent forest complexes containing valuable plants. It is located on the Gryfice Plain, near the village of Rokita, in a moraine upland area in the Kamień Pomorski anticline, and occupies two shallow depressions in the ground moraine landscape, separated by a small hill, and a flat moraine plain in the northern part of the reserve, with a moraine kame at $40 \mathrm{~m}$ a.s.l. situated on the north-western border of the reserve (Kondracki, 2004).

The southern depression is occupied by Lake Żabie, a small dystrophic lake located in a transitional, topogenous peat bog. The depression occupying the central part of the reserve is entirely filled with peat. In the eastern part it is a transitional, topogenous bog, while in the western part it is a raised, ombrogenous bog.

The research area was divided into eight sites, to more fully show the species richness of the entire reserve. The sites were classified as follows: sphagnum phytocoenoses with fragments of pine forest, Sphagno squarrosi-Alnetum, Ribeso nigri-Alnetum, ash and alder riparian forest, sphagnum peat bog, Vaccinio uliginosi-Betuletum pubescentis, phytocoenoses mainly dominated by sub-Atlantic lowland oak and hornbeam forest, phytocoenoses mainly dominated by Vaccinio uliginosi-Betuletum pubescentis.

\section{Methods}

The study was carried out from 28 May to 15 August 2006. Due to the fact that the studies were conducted in the nature reserve, the duration of the study and the number of traps used were limited.

The beetles were caught using Barber traps, each consisting of a plastic $500 \mathrm{ml}$ container buried in the earth so that its rim did not protrude above the surface, making it much easier for insects to fall in. About $15 \mathrm{ml}$ of a $10 \%$ solution of ethylene glycol was poured into the container. A plastic lid was placed about $2 \mathrm{~cm}$ over the trap to protect it from rain and falling leaves that could block the opening. This is a standard method that is widely used in this type of research (Thiele, 1977).

The habitat preferences of each species were based on a work by Koch (1989) and Aleksandrovich (2004). 


\section{Results}

In the Golczewskie Uroczysko Nature Reserve 2,141 beetles were captured and identified, comprising 58 species from 7 families (Table 1).

The most abundant families were Carabidae, with 34 species and 1,108 specimens, Silphidae, with 8 species and 631 specimens, Staphylinidae 4 species and 18 specimens, and Geotrupidae, with 3 species and 315 specimens (Table 1).

Table 1. List of families of epigeic beetles

\begin{tabular}{|l|c|c|}
\hline \multicolumn{1}{|c|}{ Family } & Number of species & Number of specimens \\
\hline Carabidae & 34 & 1,108 \\
\hline Catopidae & 2 & 45 \\
\hline Elateridae & 6 & 22 \\
\hline Geotrupidae & 3 & 315 \\
\hline Silphidae & 8 & 631 \\
\hline Staphylinidae & 4 & 18 \\
\hline Tenebrionidae & 1 & 2 \\
\hline Total & 58 & 2,141 \\
\hline
\end{tabular}

Table 2. List of families and species of epigeic beetles caught in Barber traps

\begin{tabular}{|c|c|c|c|}
\hline Family & Species & $\begin{array}{c}\text { Number } \\
\text { of specimens }\end{array}$ & $\begin{array}{c}\text { Habitat } \\
\text { preferences }\end{array}$ \\
\hline 1 & 2 & 3 & 4 \\
\hline \multirow{18}{*}{ Carabidae } & Agonum ericeti (Panzer, 1809) & 1 & peatland \\
\hline & Agonum fuliginosum (Panzer, 1809) & 2 & forest \\
\hline & Agonum hypocrita (Apfelbeck, 1904) & 2 & peatland \\
\hline & Amara plebeja (Gyllenhal, 1810) & 2 & grassland \\
\hline & Calathus micropterus (Duftschmid, 1812) & 5 & forest \\
\hline & Carabus arcensis (Herbst, 1784) & 44 & forest \\
\hline & Carabus auratus (Linnaeus, 1761) & 2 & field \\
\hline & Carabus convexus (Fabricius, 1775) & 18 & forest \\
\hline & Carabus coriaceus (Linnaeus, 1758) & 17 & forest \\
\hline & Carabus glabratus (Paykull, 1790) & 152 & forest \\
\hline & Carabus granulatus (Linnaeus, 1758) & 138 & eurybiont \\
\hline & Carabus hortensis (Linnaeus, 1758) & 120 & forest \\
\hline & Carabus nemoralis (O.F.Müller, 1764) & 1 & eurybiont \\
\hline & Carabus violaceus (Linnaeus, 1758) & 116 & forest \\
\hline & Chlaenius nitidulus (Schrank, 1781) & 1 & grassland \\
\hline & Cychrus caraboides (Linnaeus, 1758) & 7 & forest \\
\hline & Harpalus rufipes (Degeer, 1774) & 1 & field \\
\hline & Leistus terminatus (Hellwig, 1793) & 1 & peatland \\
\hline
\end{tabular}




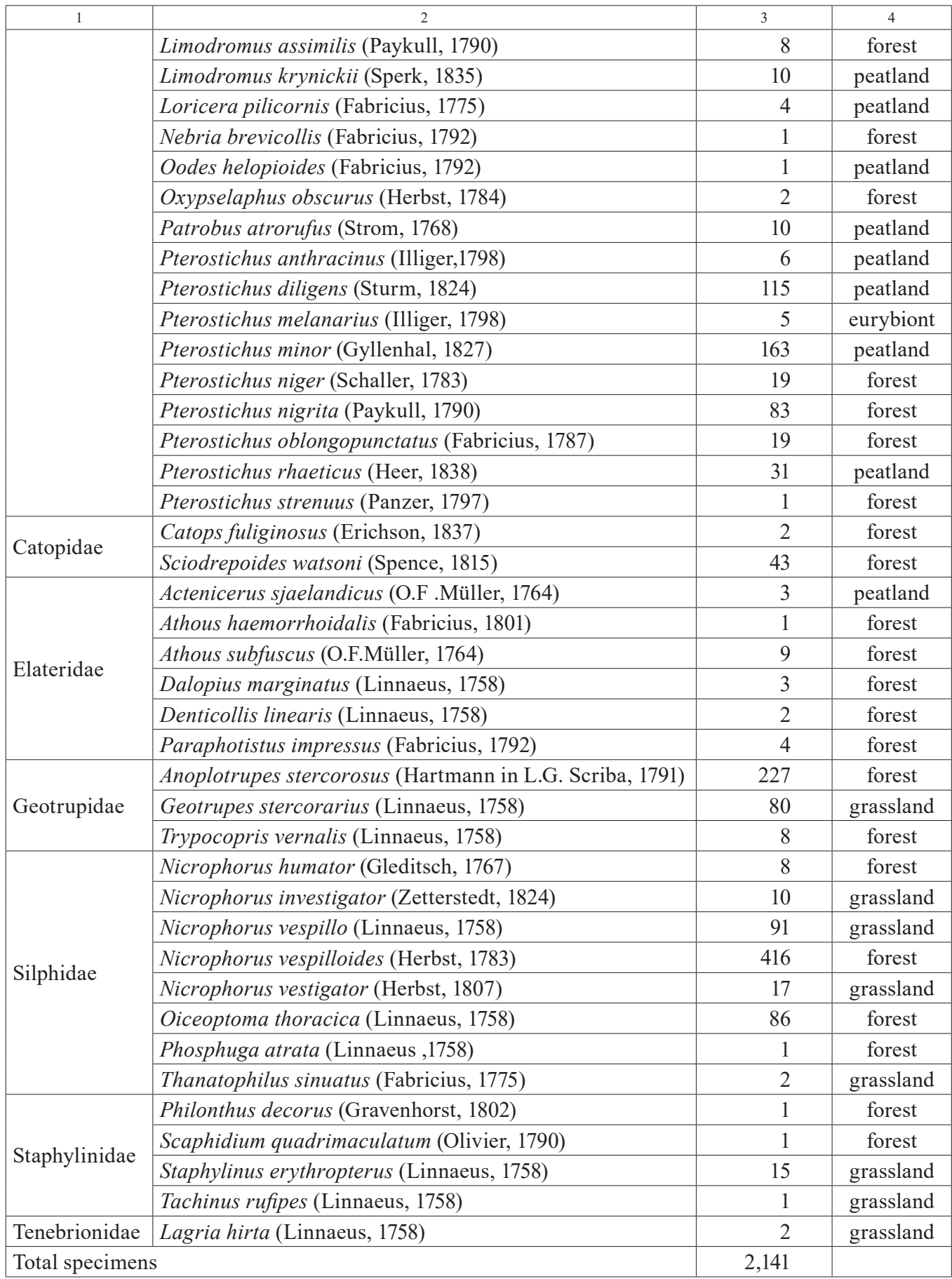




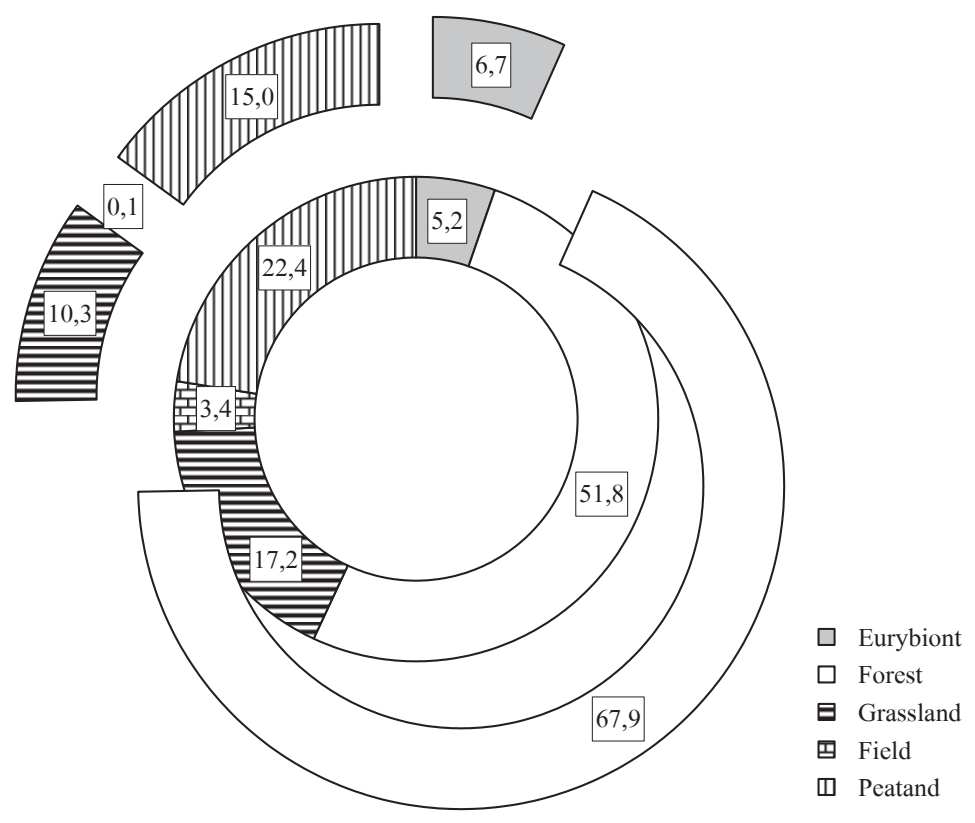

Figure 2. Habitat preferences of epigeic beetles of the Uroczysko Golczewskie Nature Reserve (inner ring - number of species, outer ring - number of specimens)

The epigeic beetle fauna of the Uroczysko Golczewskie Nature Reserve is not very rich, consisting primarily of forest, grassland and peatland species (Figure 2).

The presence of three ground beetle species under partial protection was established: Carabus convexus, Carabus coriaceus and Carabus glabratus (Dz.U. [Journal of Laws] of 2016, item 2183). These species are fairly abundant in forest habitats (phytocoenoses dominated by sub-Atlantic lowland oak and hornbeam forests) and their populations are not endangered.

Three species are on the Polish Red List of endangered species (Pawłowski et al., 2002): the near threatened (NT) Carabus convexus and the vulnerable (VU) Agonum ericeti and Oodes helopioides.

The most ecologically valuable are stenobiontic hygrophilous species typical of raised bogs: ground beetles Agonum ericeti, Pterostichus diligens and Pterostichus rhaeticus and of transitional bogs and fens ground beetles Agonum hypocrita and Limodromus krynickii, the click beetle Paraphotistus impressus.

Also included among peatland species were hygrophilous species which, apart from peatlands, are also found in other wetlands: Actenicerus sjaelandicus, Leistus terminatus, Loricera pilicornis, Oodes helopioides, Patrobus atrorufus, Pterostichus anthracinus and Pterostichus minor.

Agonum ericeti - a stenobiontic hygrophilous species of raised bogs. One species caught 1 July 2006 in a raised peat bog. Recorded the first time for West Pomerania. 
Agonum hypocrita - a stenobiontic hygrophilous species of lowland and carbonate fens. Rarely encountered in Pomerania (http://baza.biomap.pl/pl/taxon/order-coleoptera/default/tlm/ checklist). Two specimens caught 9 August 2006 in a peat bog with fragments of pine forest.

Limodromus krynickii - a stenobiontic hygrophilous species of lowland fens. Rarely encountered in Poland (Burakowski et al., 1974). Recorded for the first time for Pomerania. One specimen, caught 28 May 2006 in a Vaccinio uliginosi-Betuletum pubescentis association.

Pterostichus rhaeticus - a stenobiontic hygrophilous species of raised bogs. 21 species caught on 9 August 2006 in a raised peat bog, 6 specimens in a peat bog with fragments of pine forest, and 4 in a Sphagno squarrosi-Alnetum association.

Oodes helopioides - a stenobiontic hygrophilous species of peatlands and other wetlands. Common in Poland (http://baza.biomap.pl/pl/taxon/species-oodes_helopioides_helopioides/ default/tr/y). Caught on 28 May 2006, one specimen in a Vaccinio uliginosi-Betuletum pubescentis association.

Paraphotistus impressus - rare and sporadic species associated with coniferous forests (Burakowski et al., 1985). Four specimens caught on 9 August 2006, in a peat bog with fragments of pine forest.

\section{Discussion}

Peatlands are considered very demanding, extreme environments (Främbs et al., 2002). Species strictly associated with these biotas are called tyrphobionts, while those occurring in the highest numbers, but with a broader ecological spectrum, have been classified as tyrphophiles (Peus, 1932). The tyrphobiontism of numerous taxa occurring in marshes and peatlands is the result of regional limitations. Most of these species are eurytopes which have spread in the continental regions of Eurasia, while in Central and Western Europe their occurrence is limited to oligotrophic peatlands (Thiele, 1977). In the Uroczysko Golczewskie reserve, Agonum ericeti and Pterostichus rhaeticus belong to this group.

In the study area we can observe that the species occurring in the highest numbers are representatives of the Carabidae and Silphidae families. The first of these are predatory species which actively seek prey, while the latter are scavengers (apart from the predatory Phosphuga atrata and the polyphagous Thanatophilus sinuatus).

Tews et al. (2003) found that species richness is most affected by habitat structure in periodically flooded wetlands. It is likely that the mosaic character of the habitats in the Uroczysko Golczewskie reserve had a significant effect on species diversity.

Comparison of the species composition of the epigeic beetles of the Uroczysko Golczewskie reserve indicates a fairly high degree of similarity with the fauna of peatlands of NW Germany (Peus, 1932, Mossakowski, 1970), NE Poland (Aleksandrowicz et al., 2017) and northern Belarus (Sushko, 2006).

\section{Conclusions}

The study was conducted in May-August 2006 in the Golczewskie Uroczysko Nature Reserve, UTM WV06. Ten Barber traps with ethylene glycol were used to catch 2,141 beetles belonging to 58 species from 7 families. 
The most abundant families were Carabidae, with 34 species and 1,108 specimens, Silphidae, with 8 species and 631 specimens, and Geotrupidae, with three species and 315 specimens.

The epigeic beetle fauna of the reserve consisted mainly of forest, grassland and peatland species.

The presence of three species of ground beetles under partial protection was established: Carabus convexus, Carabus coriaceus and Carabus glabratus (Dz.U. [Journal of Laws] of 2016, item 2183). These species are fairly abundant in forest habitats (phytocoenoses dominated by sub-Atlantic lowland oak and hornbeam forests) and their populations are not endangered.

Three species are on the Polish Red List of endangered species (Pawłowski et al., 2002): the near threatened (NT) Carabus convexus and the vulnerable (VU) Agonum ericeti and Oodes helopioides.

The most ecologically valuable species include hygrophilous peatland species: Agonum ericeti, Pterostichus rhaeticus, Agonum hypocrita, Limodromus krynickii, Oodes helopioides, the rare click beetle Paraphotistus impressus, all of which have poorly known ecological preferences.

Comparison of the species composition of the epigeic beetles of the Uroczysko Golczewskie reserve indicates a fairly high degree of similarity with the fauna of peatlands of north-western Germany and northern Belarus.

\section{References}

Aleksandrovich, O.R. (2004). List of species. Wykaz gatunków - Coleoptera: Carabidae. In: W. Bogdanowicz, E. Chudzicka, I. Pilipiuk, E. Skibińska (eds.), Fauna Polski-charakterystyka i wykaz gatunków (1, pp. 32-42). Warszawa: MiIZ PAN.

Aleksandrowicz, O. (2014). Ground beetles (Coleoptera, Carabidae) west of the forest zone of the Russian Plain. Fauna, zoogeography, ecology, faunogenesis. Saarbrücken: Lambert Academic Publishing.

Aleksandrowicz, O.R., Browarski, B., Stachowiak, M. (2017). Ground beetles (Coleoptera, Carabidae) of the marsh complex "Torfiaki" (Mazuian Lakeland). In: OV Yanchurevich et al. (eds.), Zoological readings - 2017: Proceeding of the International Scientific and Practical Conference (Grodno, March 15-17, 2017), (pp. 11-19). Grodno [in russian].

Burakowski, B., Mroczkowski, M., Stefańska, J. (1974). Chrzaszcze-Coleoptera. Biegaczowate-Carabidae 2. Katalog Fauny Polski. Cz. 23, t. 3. Warszawa: PWN.

Burakowski, B., Mroczkowski, M., Stefańska, J. (1985). Chrzązcze-Coleoptera. Buprestoidea, Elateroidea i Cantharoidea. Katalog Fauny Polski. T. 23, z. 10. Warszawa: PWN.

Council Directive 92/43/EEC of 21 May 1992 on the conservation of natural habitats and of wild fauna and flora - Natura 2000.

Främbs, H., Dormann, W., Mossakowski, D. (2002). Spatial distribution of carabid beetles on Zehlau Bog. Baltic J. Coleopterol., 1 (2), 7-13.

Ilnicki, P. (2002). Torfowiska i torf. Poznań: Wydawnictwo AR w Poznaniu.

Koch, K. (1989). Die Käfer Mitteleuropas. Ökologie. Krefeld: Goecke \& Evers Verlag.

Kondracki, J. (2004). Geografia Fizyczna Polski. Warszawa: PWN.

Krogerus, R. (1960). Ökologische Studien über nordischer Moorarthropoden. Artendbestand, ökologische Faktoren, Korrelation der Arten. Commentat. Biol., 3 (21), 238.

Kuśka, A. (1995). Omomitki (Coleoptera, Cantharidae): Cantharinae i Silinae Polski. Monografie Fauny Polski. T. 21. Warszawa: PWN. 
Mossakowski, D. (1970). Ökologische Untersuchungen an epigäischen Coleopteren atlantischer Moor- und Heidestandorte. Z. Wiss. Zool., 1-2 (181), 233-316.

Mossakowski, D., Främbs, H., Lakomy, W. (2003). The Carabid and Staphylinid fauna of raised bogs. A comparison of Northwest Germany and the Baltic region. Baltic J. Coleopterol., 2 (3), 137-144.

Pawłowski, J., Kubisz, D., Mazur, M. (2002). Coleoptera Chrząszcze. Czerwona lista zwierząt ginących i zagrożonych w Polsce. In: Z. Głowaciński (ed.), Red list of threatened animals in Poland. Polish Academy of. Sciences, institute of Nature Conservation PAS (pp. 88-110). Kraków: Polska Akademia Nauk, Instytut Ochrony Przyrody.

Peus, F. (1928). Beitrage zur Kenntnis der Tierwelt nordwestdeutscher Hochmoore. Eine ökologische Studie. Insekten, Spinnentiere (teilw.). Wirbeltiere. Z. Morphol. Ökol. Tiere, 12, 533-683.

Peus, F. (1932). Die Tierwelt der Moore unter besonderer Berücksishtigung der europaischen Hochmoore. Hendbuch der Moorkunde III. Berlin.

Renkonen, O. (1938). Statistisch-ökologische Untersuchungen über die terrestrische Käferwelt der finnischen Bruchmoore. Ann. Zool. Soc. Zool,-Boot. Fennicae, 1 (6).

Roubal, J. (1934). Die Coleopterenwelt (Thyrphobionte, Tyrphophile, Tyrphoxene etc.) der Treboner (Wittingauer) Moore. Folia Zool. Hydrobiol., 7, 56-97.

Sjörs, H. (1983). Mires of Sweden. In: A.J.P. Gore (ed.), Ecosystems of the world Vol. 4B. Mires: swamp, bog, fen, moor. Regional studies. Amsterdam-Oxford-New York: Elsevier Scientific Publishing Company.

Skwarra, E. (1929). Die Käferfauna des Zehlaubruches (Beitr. Zur Fauna des Zehlau-Hochmoores in Ostpreussen, VI). Schriften der Königlichen Physikalisch-Ökonomischen Gesellschaft zu Königsberg, 2 (66), 181-274.

Sushko, G.G. (2006). Fauna and ecology of Coleoptera (Ectognatha, Coleoptera) of the raised peat-bog of the Byelorussian Poozerye. Vitebsk: VSU them. PM Masherov.

Tews, J., Brose, U., Grimm, V., Tielbörger, K., Wichmann, M.C., Schwager, M., Jeltsche, F. (2004). Animal species diversity driven by habitat heterogeneity/diversity: the importance of keystone structures. J. of Biogeography, 31, 79-92.

Thiele, H.U. (1977). Carabid beetles in their environments. A Study on Habitat Selection by Adaptation in Physiology and Behaviour. Berlin-Heidelberg-New York: Springer-Verlag.

Żurek S. (1987). Złoża torfowe Polski na tle stref torfowych Europy. Dokumentacja Geograficzna, 4.

Cite as: Radawiec, B., Baran, Ł., Śmietana, P., Sarnacka, E., Zawal, A. (2017). Preliminary data on the epigeic beetle fauna (Coleoptera) of the Golczewskie Uroczysko Nature Reserve. Acta Biologica, 24, 19-27. DOI: 10.18276/ab.2017.24-03. 